\title{
The aqueous extract of Gerrardanthus macrorhizus caudex enhanced doxorubicin activity in MCF-7 human breast cancer cells
}

\author{
Sari Haryanti ${ }^{1, *}$, Yuli Widiyastuti ${ }^{1}$, and Slamet Wahyono ${ }^{1}$ \\ ${ }^{1}$ Medicinal Plant and Traditional Medicine Research and Development Centre, Jalan Raya Lawu No. 11, Tawangmangu, Kalisoro, \\ Karanganyar, Jawa Tengah 57792, Indonesia \\ *Corresponding author: sari.haryanti@gmail.com
}

SUBMITTED 22 September 2017 REVISED 4 February 2018 ACCEPTED 11 February 2018

\begin{abstract}
Gerrardanthus macrorhizus (GM) caudex, is traditionally used in cancer therapy by the Tetun people in Belu District, East Nusa Tenggara Province, Indonesia, where it is known as "akar batu". This study aimed to explore the cytotoxic effects of G. macrorhizus caudex aqueous extract, as well as its combination with doxorubicin, on MCF-7 cells. Also investigated were the possible mechanisms of interaction through cell cycle progression and apoptosis induction. Single treatments of $5-320 \mu \mathrm{g} / \mathrm{mL}$ of the extract showed morphological alterations in MCF-7 cells, but did not show any cytotoxic effect. Combining the extract with doxorubicin resulted in a synergistic cytotoxic effect. Doxorubicin concentrations equivalent to $1 / 12$, $1 / 8$, and $1 / 5$ fold of the $\mathrm{IC}_{50}$ combined with $20 \mu \mathrm{g} / \mathrm{mL}$ decreased viability to $48 \%$. We then explored the combination effect of doxorubicin $0.4 \mu \mathrm{M}$ with GM 5 and $20 \mu \mathrm{g} / \mathrm{mL}$ using a flow cytometer. A low concentration of the extract $(5 \mu \mathrm{g} / \mathrm{mL})$ combined with $0.4 \mu \mathrm{M}$ of doxorubicin resulted in slight cell cycle modulation by G1, G2M arrested and apoptosis induction. The combination of doxorubicin and a higher concentration of the extract $(20 \mu \mathrm{g} / \mathrm{mL})$ did not show cell cycle modulation, and led to necrosis. Therefore, G. macrorhizus caudex at low concentrations has the potential to be developed further as a co-chemotherapeutic agent.
\end{abstract}

KEYWORDS apoptosis; cell cycle; cytotoxic; doxorubicin; Gerrardanthus macrorhizus; MCF-7

\section{Introduction}

Plants have been used as primary source of medicines for thousands of years. Secondary metabolites in plants have been the most promising and potential source of drug discovery leads (Dias et al. 2012). Various pharmacological target including cancer becomes important leads of medicinal plant drug discovery. Recently, plant secondary metabolites and their derivatives have been adjusted in most clinical application treatment against cancer.The field of chemoprevention also played an important role in cancer treatment. Chemoprevention is one of strategy towards combating cancer by administration of synthetic or natural compounds to reverse or suppress carcinogenesis. Chemopreventive agents perform through various actions interfering initiation, promotion, and progression of carcinogenesis (Balunas and Kinghorn 2005).

Cancer is of a significant health concern and a leading cause of death worldwide. The major contributor of cancer is strongly related to family history, involvement of lifestyle, and other environmental factors with a defective gene (Kamil and Kamil 2015). In many countries, cancer is the second leading cause of death following cardiovascular diseases (Ma and Yu 2006). Breast cancer remains a major challenge, the most frequently diagnosed and the leading cause of cancer death among women. It accounts $25 \%$ of the total cancer cases (1.68 million) and $15 \%$ of the cancer deaths $(520,000)$ worldwide. Adjuvant systemic therapy has used widespread and contributed to diminish breast cancer mortality rates.(Anampa et al. 2015). Doxorubicin is one of the most commonly used chemotherapeutic for many types of cancers including breast cancer. Doxorubicin inhibits topoisomerase I and II, and also intercalates into DNA to interfere with its uncoiling, finally inducing programmed cell death (apoptosis). The greatest risk of doxorubicin is cardiotoxicity, causing the enlargement of cardiomyocytes. Thus, doxorubucin administration must be dose-limited (Tacar et al. 2013). The reduction of doxorubicin dose might be achieved through the combination with chemopreventive agent.

The combination of natural chemopreventive agent and conventional chemotherapy is one of promising application in cancer treatment. Rational combination is expected to provide simultaneous action to create more susceptible cancer cells and to exploit the chances for better efficacy, decreased toxicity, and reduced drug resistance development (Foucquier and Guedj 2015). Our unpublished study in 2012 (National Research on Medicinal 
Plant and Jamu, RISTOJA) resulted some plants used for traditional cancer treatment. One of those plants is Gerrardanhus macrorhizus Harv. ex Benth. \& Hook.f. which belongs to Cucurbitaceae family, and characterized with unique caudex above the ground. So, commonly people use it as decorative plant. The caudex is used by traditional healers in Tetun ethnic for cancer therapy in Belu Distric, Nusa Tenggara Timur Province, Indonesia. The anticancer activity of this plant have not been explored so far. Therefore, this present study was aimed to explore the cytotoxic effect of $G$. macrorhizus caudex aqueous extract in MCF-7 human breast cancer cell line, and its combination effect with doxorubicin. We also investigated the possible mechanisms of interaction between doxorubicin and the extract through cell cycle progression and apoptosis induction by flow cytometer.

\section{Materials and methods}

\subsection{Materials and extraction}

G. macrorhizus (GM) caudex was obtained from Belu Distric, Nusa Tenggara Timur Province, Indonesia. The caudex was sliced, dried in $40^{\circ} \mathrm{C}$, grinded, and boiled with aquadest $90^{\circ} \mathrm{C}$ for $10 \mathrm{~min}$, then filtered. The supernatant was dried in oven $40^{\circ} \mathrm{C}$ for $\pm 3 \mathrm{~d}$ to obtain dried extract. The extract $10.0 \mathrm{mg}$ and doxorubicin $5.0 \mathrm{mg}$ was dissolved in $100 \mu \mathrm{L}$ DMSO (Sigma), and freshly diluted in culture medium in several concentration before used. The exact concentration were mentioned in a part of MTT assay.

\subsection{Cell culture}

MCF-7 cell lines were obtained from ATCC, and maintained in Laboratory of Molecular Biology, the Medicinal Plant and Traditional Medicine Research and Development Centre, the Ministry of Health, Tawangmangu, Jawa Tengah, Indonesia.

\subsection{Morphological observation and cytotoxic MTT as- say}

The MCF-7 cells were cultured in $10 \mathrm{~mm}$ dish with Minimum Essential Medium (MEM Gibco) containing $10 \%$ fetal bovine serum/FBS (Gibco), 1\% penicillinstreptomycin (Gibco), and incubated in $\mathrm{CO}_{2}$ incubator $5 \%$ at $37^{\circ} \mathrm{C}$. When the cells were already confluent, the medium was discarded, washed with phosphate buffer saline (PBS Sigma) 1x, and added trypsin EDTA $0.25 \%$ to detach cells. Harvested cells were counted using a haemocytometer. Approximately 1x10 4 MCF-7 cells/well were seeded in 96-well plates and incubated for $48 \mathrm{~h}$. Cells were treated with increasing concentration of GM extract $(10,20,40,80,160$, and $320 \mu \mathrm{g} / \mathrm{mL})$ or doxorubicin $(0.3$, $0.5,1.1,2.2,4.4,8.8$, and $11 \mu \mathrm{M})$ for $24 \mathrm{~h}$. Morphological observation of the cells were done under inverted microscope, and documented using digital camera (Canon Ixus). Then, cultured medium was removed and cells were washed with PBS (Sigma). MTT $0.5 \mathrm{mg} / \mathrm{mL}$ in medium were added into each well and incubated for 3-4 h. MTT reaction was stopped by the addition of SDS $10 \%$ in $\mathrm{HCl}$ $0.01 \mathrm{~N}$, and incubated overnight in the dark room. The absorbance was measured using ELISA reader at $\lambda 595 \mathrm{~nm}$ (Biorad). Each treatment were carried out in triplicate, and the absorbance data are provided as percentage of viability compared to control cells without treatment (untreated, only cultured medium added). The combination assay was done using the same method. The concentration used in combination treatment were below the $\mathrm{IC}_{50}$ value of single doxorubicin and GM extract. In this research, we combined GM 5.0, 7.5, 15.0, and $20.0 \mu \mathrm{g} / \mathrm{mL}$ with doxorubicin $0.4,0.6$, and $1.3 \mu \mathrm{M}$. Each concentration was combined with others (12 combinations) and performed in triplicate.

\subsection{Cell cycle result and apoptosis induction by flow cytometry assay}

Approximately $5 \times 10^{5} \mathrm{MCF}-7$ cells/well were cultured in 6 well plate and incubated for $48 \mathrm{~h}$. Cells were then treated with G. macrorhizus and doxorubicin, either alone or combination for $24 \mathrm{~h}$. Cells were harvested with trypsin EDTA, washed in phosphate-buffered saline (PBS), and centrifuged $500 \mathrm{rpm}$ for $5 \mathrm{~min}$. For apoptosis induction, cells then incubated with annexin-V-FITC and propidium iodide (BD Pharmingen) for $15 \mathrm{~min}$ in the dark, and analyzed using BD Accuri C6 Flowcytometer. To determine cell cycle distribution, cells were fixed with cold ethanol $70 \%$ for $30 \mathrm{~min}$, washed with PBS, and centrifuged 500 rpm for $5 \mathrm{~min}$. Cells were then resuspended in PBS containing $40 \mu \mathrm{g} / \mathrm{mL}$ propidium iodide (Sigma), $20 \mu \mathrm{g} / \mathrm{mL}$ RNAse (Roche) and 0.1\% TritonX-114 (Sigma) for $15 \mathrm{~min}$ in the dark, and then subjected to BD Accuri C6 flowcytometer for further analysis.

\subsection{Data analysis}

To calculate the $\mathrm{IC}_{50}$ value from single cytotoxicity assay, we plotted linear regression of concentration and percent-

TABLE 1 Interpretation of $\mathrm{Cl}$ value representing potency of combinational application (Reynolds and Maurer 2005).

\begin{tabular}{llll}
\hline $\mathrm{Cl}$ & Interpretation & $\mathrm{Cl}$ & Interpretation \\
\hline$<0.10$ & Very strong synergist & $0.90-1.10$ & Closely additive \\
$0.10-0.30$ & Strongly synergist & $1.10-1.45$ & Middle antagonist \\
$0.30-0.70$ & Synergist & $1.45-3.30$ & Antagonist \\
$0.70-0.90$ & Middle synergist & $>3.30$ & Strongly antagonist \\
\hline
\end{tabular}


age of cells viability using MS Excel 2013. Combination treatment was evaluated by calculating the Combination Index (CI) value with the following formula:

$$
C I=D 1 / D x 1+D 2 / D x 2
$$

D1 and D2 described the concentrations used in combinational treatment, while Dx1 and Dx2 are single treatment concentration giving the same response as D1 and D2, respectively. Interpretation of CI value was represented as listed in Table 1 (Reynolds and Maurer 2005). The data obtained from flow cytometer was analyzed using BD Accuri C6 software, and evaluated with the Student t-Test Paired Two Samples for Means. In all analyses, $\mathrm{p}<0.05$ was considered to be statistically significant.

\section{Results}

\subsection{Cell growth inhibitory effect by single treatment of G. macrorhizus and doxorubicin}

Cytotoxic activity of GM caudex aqueous extract on MCF7 cells were done by MTT assay. The cells treated with single extract in all concentrations $(10-320 \mu \mathrm{g} / \mathrm{mL})$ showed morphological changes similar to cell death configuration. They were detected to become losing their shapes, forming wider intercell spaces, getting shrinkage, and appeared in visibly different as compared to medium control cells (Figure 1a). However, when MTT was added to the cells, formazan crystal were formed just like in untreated cells (Figure 1b). The MTT should be converted into purple colored formazan by viable cells with active metabolism which involves reaction with NADH or similar reducing molecules. Thus, formazan formation presents as a useful and appropriate marker of only viable cells (Riss et al. 2016). In this research, the analysis of formazan color absorbance vs cell viability showed no difference effect with untreated cells (Figure 1c). It means that cells treated with
GM extract, although showing a morphological changes, they were remained viable and still having ability to convert MTT into formazan.

Meanwhile, cells treated with doxorubicin for $24 \mathrm{~h}$ resulted in growth inhibition and cell death in a dose and time dependent manner, as shown in Figure 2. The IC $_{50}$ determination of doxorubicin by linear regression was 5 $\mu \mathrm{M}$ (Figure 2).

Based on the MTT assay results of single doxorubicin and GM extract, we were then assessed the combination effect of GM extract and doxorubicin in some series concentration on MCF-7 cells.

\subsection{Combined effect of G. macrorhizus extract with doxorubicin on MCF-7 cell viability}

The combination assay was done using concentration below the $\mathrm{IC}_{50}$ of doxorubicin $(0.4,0.6$, and $1.3 \mu \mathrm{M})$, and the concentration of GM that already caused morphological changes (5.0, 7.5, 15.0, and $20.0 \mu \mathrm{g} / \mathrm{mL}$ ). Increasing concentration of $G$. macrorhizus extract and doxorubicin in combination was followed by a decreasing cell viability, and resulted in the CI value less than 1, as seen in Figure 3a and $3 \mathrm{~b}$. It indicated that combinational treatment of GM extract and doxorubicin exhibited a synergistic inhibitory effect on MCF-7 cells viability rather than additive or antagonistic. Strongly synergist was achieved at the lowest and middle concentration of doxorubicin $(0.4 \mu \mathrm{M}$ and 0.6 $\mu \mathrm{M})$ each combined with the middle and highest concentration of the extract (10 and $20 \mu \mathrm{g} / \mathrm{mL}$ ) successively.

\subsection{Cell cycle progression and apoptosis induction}

The combined effect of doxorubicin and the extract on cell growth inhibition could be developed as the result of cell cycle modulation and apoptosis induction. To investigate its synergistic mechanism, we further explored MCF7 cell cycle progression and cell death using a flow cytome- (a)

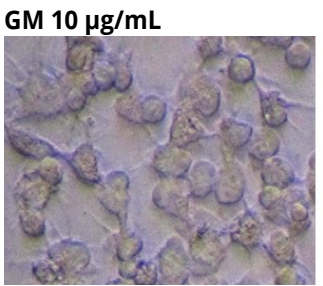

(b)

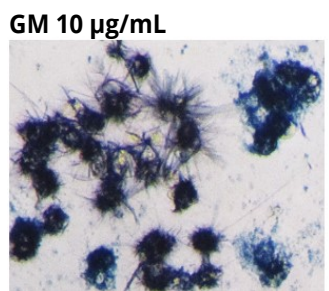

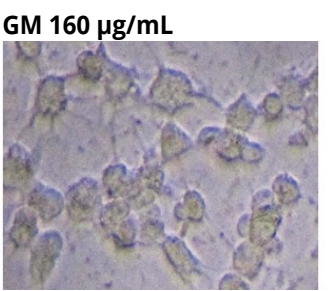

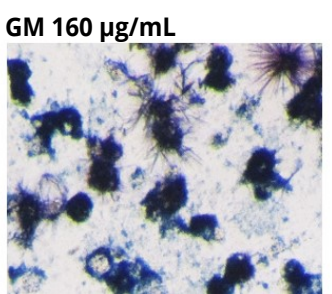

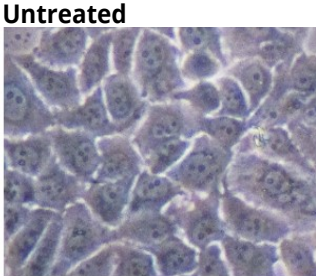

Untreated

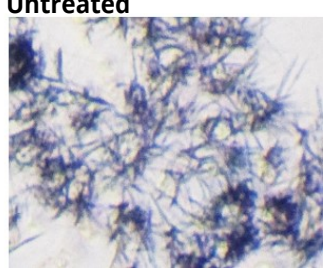

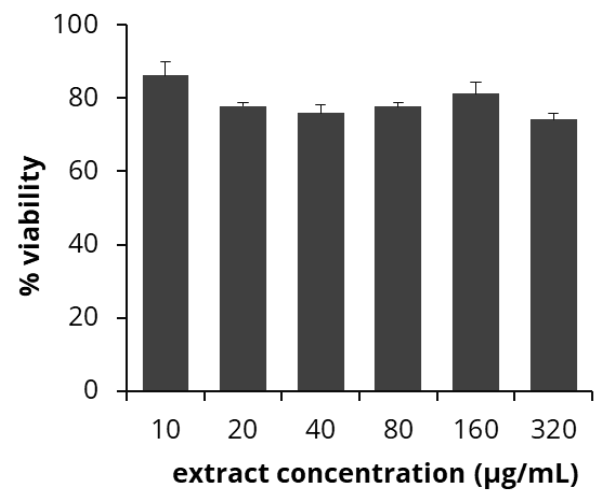

(c)

FIGURE 1 Morphological changes of MCF-7 cells treated by GM 10 and $160 \mu \mathrm{g} / \mathrm{mL}$ for $24 \mathrm{~h}$ compared to untreated cells. (a) MCF-7 cells before MTT addition; and (b) formazan crystal formation formed by the cells after MTT assay, both taken under inverted microscope with $200 x$ magnification; (c) the viability vs GM concentration. The MTT assay was performed in triplicate, data represented as mean \pm SD of percentage of cell viability. GM: G. macrorhizus extract 


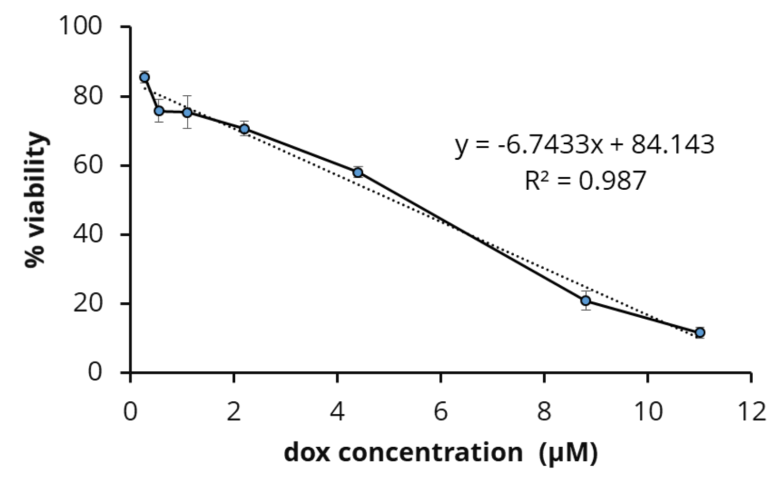

FIGURE 2 The effect of doxorubicin for $24 \mathrm{~h}$ on MCF-7 cells viability. The MTT assay was performed in triplicate, data are represented as mean \pm SD of percentage of cell viability.

ter. Two combinations were selected, doxorubicin $0.4 \mu \mathrm{M}$ - extract $5 \mu \mathrm{g} / \mathrm{mL}$ for middle synergist (CI 0.7) and doxorubicin $0.4 \mu \mathrm{M}$ - extract $20 \mu \mathrm{g} / \mathrm{mL}$ for strong synergist (CI 0.1). Cell cycle analysis of the treatment is shown in Figure 4. Single treatment of doxorubicin $0.4 \mu \mathrm{M}$ slightly induced G2/M arrested (33.5\%), while extract $5 \mu \mathrm{g} / \mathrm{mL}$ slightly induced G1 arrested (61.1\%), and their combination induced both G1 (58.4\%) and G2/M (30.9\%) arrested, compared to untreated cells $27.6 \%$ and $52.9 \%$ successively. Single treatment of extract $20 \mu \mathrm{g} / \mathrm{mL}$ combined with doxorubicin $0.4 \mu \mathrm{M}$ both significantly increased cell population in subG1 compared to untreated cells.

To understand cell death mechanism in subG1 population, whether synergistic combination was mediated through apoptosis, we stained treated cells with propidium iodide-annexin and subjected to flow cytometer as seen in Figure 5. The results showed the apoptotic population was significantly increased in MCF-7 cells treated by combination of doxorubicin $0.4 \mu \mathrm{M}$ with extract $5 \mu \mathrm{g} / \mathrm{mL}$ (7.6\%) and also by doxorubicin $0.4 \mu \mathrm{M}$ with extract $20 \mu \mathrm{g} / \mathrm{mL}$ (8.2\%). Both was compared with control cells (1.8\%) and any single treatment (doxorubicin (2.7\%), extract $5 \mu \mathrm{g} / \mathrm{mL}$ (2.1\%), extract $20 \mu \mathrm{g} / \mathrm{mL}(2.6 \%))$.

\section{Discussion}

Doxorubicin is one of the most active chemotherapy agent and widely used for breast cancer treatment. Its application in chemotherapy is often limited due to cardiotoxicity risk and resistance progression (Zeichner et al. 2016). The development of doxorubicin resistance in breast cancer is multifactorial process, mainly associated with wide and diverse expression of drug-resistance genes. AbuHammad and Zihlif (2013), using doxorubicin resistant MCF-7 breast cancer cells proved an up-regulation of many phase I/II metabolizing genes and drug efflux pump genes and many other changes in genes responsible for cell cycle, apoptosis and DNA repair (AbuHammad and Zihlif 2013). The combination with a natural chemopreventive agent is one of promising strategy to improve doxorubicin anti-

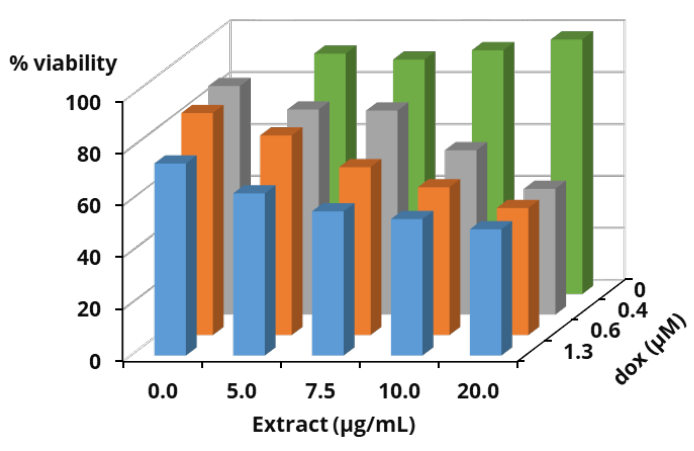

(a)

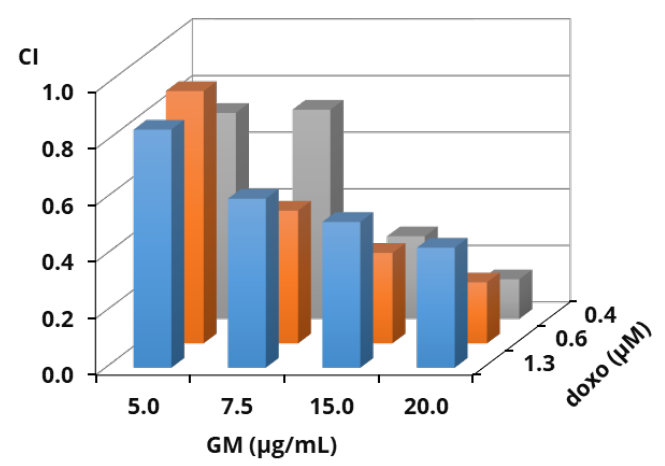

(b)

FIGURE 3 The synergistic inhibitory effect of $G$. macrorhizus extract in combination with doxorubicin on MCF-7 cell. (a) cytotoxic combination assay. Cells were treated with series combination for 24 $h$, inhibitory effect was determined with MTT assay. The assay was performed in triplicate, data are represented as mean \pm SD of percentage of cell viability (the SD values ranges $0.2-6.9$ ). (b) Combination Index $(\mathrm{Cl})$ resulted by means of cell viability in each treatment. All of the $\mathrm{Cl}$ value were $<1$, indicating synergism effect between the combination. GM: G. macrorhizus extract.

cancer effectiveness and reduce its toxicity (Ko and Moon 2015). Therefore, we investigated the modulatory effect of $G$. macrorhizus caudex aqueous extract on the doxorubicin cytotoxicity, cell cycle and apoptosis in MCF-7 human breast cancer cell line.

In this study, G. macrorhizus caudex aqueous extract was first evaluated for cytotoxicity effect to MCF-7 cells. The MTT assay revealed that the extract did not influence viability and cytotoxic effect. However, the apparent cell shrinkage was clearly observed on MCF-7 cells treated with the extract in all concentration (10-320 $\mu \mathrm{g} / \mathrm{mL})$. Cell shrinkage characterized by smaller size, dense cytoplasm and tightly packed organelles, is identified as the early sign of morphological changes during apoptosis process (Elmore 2007). Apoptosis, one of cell death design, is an ordered and orchestrated cellular process that occurs in physiological condition and pathological of many diseases. Apoptosis evasion plays a crucial role in carcinogenesis, therefore it is created as a popular target for cancer treatment strategy (Wong 2011). Based on the morphological alteration, we suggest that the extract might have ability to improve sensitivity of MCF-7 cells to doxorubicin. 

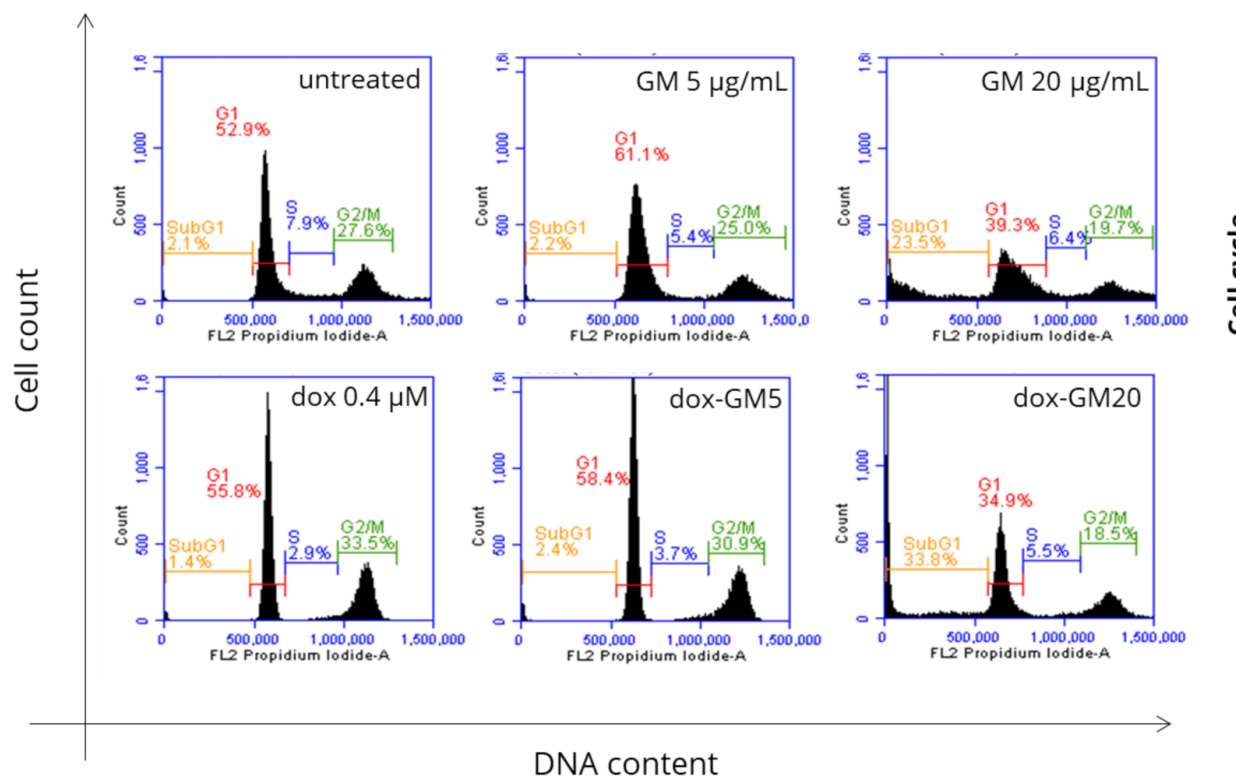

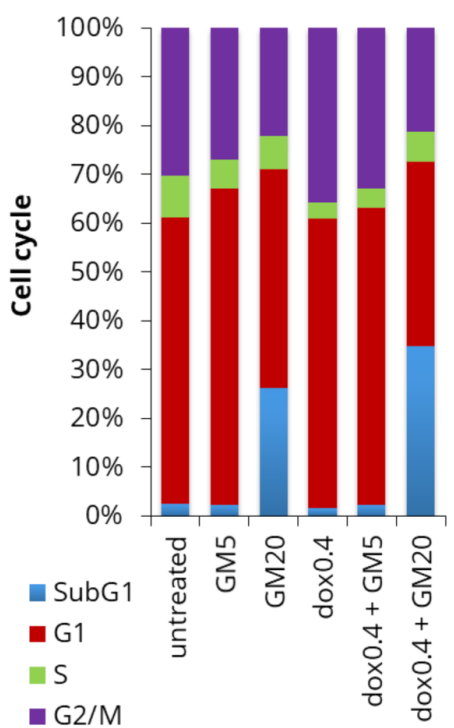

Cells treatment

FIGURE 4 Treatment of G. macrorhizus extract, doxorubicin and their combination modulated MCF-7 cell cycles. Cells were treated for $24 \mathrm{~h}$ and stained with PI reagent, each sample was subjected to flow cytometer.GM: G. macrorhizus extract.

The MTT assay of doxorubicin single treatment decreased cell viability with the $\mathrm{IC}_{50}$ value of $5 \mu \mathrm{M}$. We further demonstrated MTT assay combination for doxorubicin and the extract to obtain CI value. The CI is widely accepted as the simplest possible way to express pharmacologic drug interaction for quantifying synergism or antagonism. Synergism interaction will be very useful to treat the dreadful diseases, such as cancer. The main gains are the achievement of synergistic therapeutic effect, reduction of dose and toxicity, and also minimize or delay drug resistance (Chou 2010). In this research, we used CI values to evaluate the combination effect of doxorubicin and extract on the percentage of viability of MCF-7 cells. Based on the CI values, the extract sensitized MCF-7 cells and enhanced doxorubicin cytotoxicity by less than 1 , at any concentration level. This result was indicating that the combination obviously exerted synergistic inhibitory effect on MCF-7 viability. The smallest concentration of doxorubicin $\left(0.4 \mu \mathrm{M}\right.$ equal to 0.08 fold of $\left.\mathrm{IC}_{50}\right)$ combined with $20 \mu \mathrm{g} / \mathrm{mL}$ of extract decreased MCF-7 viability to $48.4 \%$. Therefore, the extract may lead to reducing of doxorubicin dose therapy and furthermore minimizing its cardio toxicity risk. In this study, G. macrorhizus caudex aqueous extract potentially enhanced proliferation inhibitory effect of doxorubicin on MCF-7 cells.

The most vital characteristic of cancer cells involves the ability to sustain chronic proliferation by deregulating of growth-promoting signals through the cell growth and division cycle (Hanahan and Weinberg 2011). The cell cycle is a tidy and tightly regulated mechanism by which cell divide, involving four phases namely G1, S (synthesis), G2 and M (mitosis) (Deep and Agarwal 2008). The basic processes of cell cycle development implicate the complex interaction of various proteins in a systematic and coordinated manner (Shah and Schwartz 2001). The aberrant cell cycle progression plays a crucial role in cancer cell growth, thus targeting the cell cycle have been regarded as an ideal cancer treatment (Deep and Agarwal 2008). Doxorubicin modulates cell cycle through G1 and G2 phase arrest, as the result of its interaction with topoisomerase II mediated DNA damage (Lal et al. 2010). As our result, single doxorubicin $0.4 \mu \mathrm{M}$ slightly induced cell accumulation at G1 and G2/M phase by $2.6 \%$ and $5.9 \%$ respectively but did not lead cell death, compared to untreated MCF-7 cells. The extract $5 \mu \mathrm{g} / \mathrm{mL}$ alone increased G1 while $20 \mu \mathrm{g} / \mathrm{mL}$ increased subG1 phase accumulation. The combination of doxorubicin with the extract $5 \mu \mathrm{g} / \mathrm{ml}$ enhanced cell accumulation at G1 and G2/M, compared by single doxorubicin. Furthermore, doxorubicin combined with the extract $20 \mu \mathrm{g} / \mathrm{mL}$ increased cell death in subG1 by $31.8 \%$, compared by each single treatment.

The cell cycle arrest depicted a survival mechanism for the cancer cell to repair its own damaged DNA. The disruption of cell cycle checkpoints by specific agent before completing DNA repair, can activate the apoptotic pathway leading to cell death (Schwartz and Shah 2005) Doxorubicin caused apoptosis in cancer cells by early activation of p53 followed by caspase-3 activation and DNA fragmentation (Wang et al. 2004). In our study, single treatment of doxorubicin $0.4 \mu \mathrm{M}$ and the extract 5 and 20 $\mu \mathrm{g} / \mathrm{mL}$ had no significant effect to apoptosis induction. Interestingly, the extract $20 \mu \mathrm{g} / \mathrm{mL}$ caused significant necrosis on MCF-7 cells. This was not in line with the result of cytotoxic assay. MCF-7 cells treated with the extract had still interacted with MTT to form formazan crystal. Therefore, this finding need further research to establish the ac- 

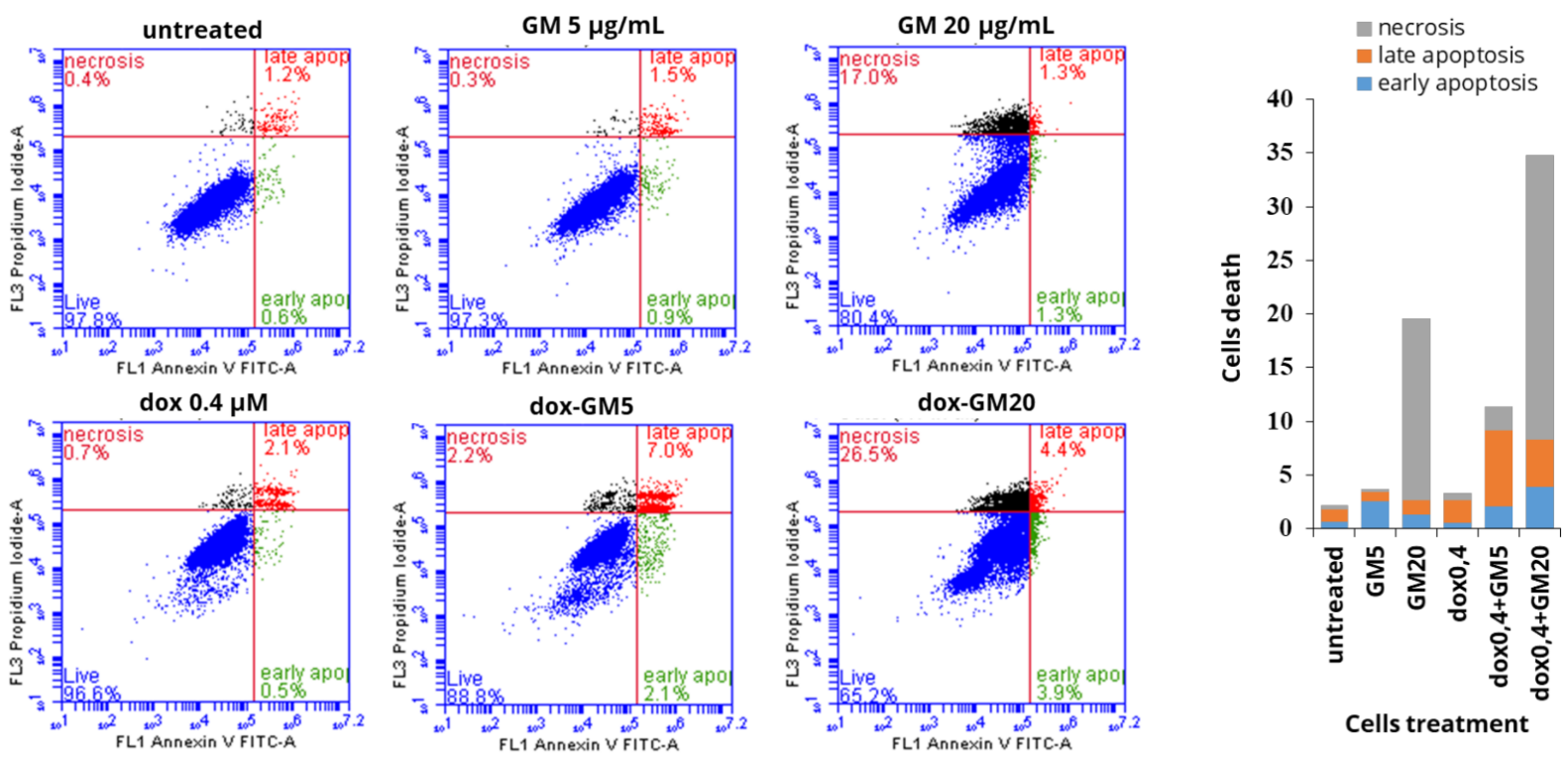

(a)

(b)

FIGURE 5 Treatment of doxorubicin and extract combination significantly induced apoptosis in MCF-7 cell. Cells were treated for $24 \mathrm{~h}$ and stained with annexin V-PI, each sample was subjected to flow cytometer in triplicate. (a) The diagrams are divided into four area, which showed distribution profiles of living cells (bottom-left), early apoptotic (bottom-right), late apoptosis (upper-right), necrosis (upper-left) in various indicated treatment. (b) Statistical analysis results for apoptosis induction for each treatment.

tual evidence occured in cells treated with high concentration of the extract. However, the combination of doxorubicin with both of the extract ( 5 and $20 \mu \mathrm{g} / \mathrm{mL}$ ) increased apoptotic and necrotic cell induction, compared by each single treatment.

Cell cycle regulation and apoptosis induction plays a critical role in malignant transformation and in the development chemotherapy resistance. These have led to the development of anticancer therapeutics that target the motors of the cell cycle specifically the cyclin dependent kinases (CDKs). The abrogation of cell cycle checkpoints at critical time by a CDKs inhibitor is expected to make the tumor cell susceptible to apoptosis. The application of CDKs inhibitor as single agents is intended to target the errors of cell cycle regulation to attain cancer cells spesific cytotoxicity.Currently, these agents are combined with conventional chemotherapy to overcome cell cycle mediated drug resistance and enhance cytotoxic efficacy (Schwartz and Shah 2005).

\section{Conclusions}

Based on these findings, G. macrorhizus caudex aqueous extract in all concentration used in this research increased and revealed synergistic effect on doxorubicin cytotoxicity. Doxorubicin concentration which equivalent with $1 / 12,1 / 8$, and $1 / 5$ fold of IC $_{50}$, combined with $20 \mu \mathrm{g} / \mathrm{mL}$ decreased viability to $48 \%$. Low concentration of the extract $(5 \mu \mathrm{g} / \mathrm{mL})$ combined with $0.4 \mu \mathrm{M}$ doxorubicin resulted slight cell cycle modulation by G1, G2M arrested and apoptosis induction. The combination with higher concentration (20 $\mu \mathrm{g} / \mathrm{mL}$ of the extract) did not show cell cycle modulation, and leading to necrosis. Therefore, the extract at low concentration performs potential natural source to be developed further as co-chemotherapeutic agent. Thus, further research is needed to find the molecular mechanism underlying the anticancer effect of $G$. macrorhizus caudex.

\section{Acknowledgments}

This research was supported by the Medicinal Plant and Traditional Medicine Research and Development Centre, the National Institute of Health Research and Development, the Ministry of Health, Indonesia.

\section{Authors' contributions}

SH, YW designed the study. SH, YW carried out the laboratory work. SH, SW analyzed the data. SH, YW, SW wrote the manuscript. All authors read and approved the final version of the manuscript.

\section{Competing interests}

The authors declare no competing interest.

\section{References}

AbuHammad S, Zihlif M. 2013. Gene expression alterations in doxorubicin resistant MCF7 breast cancer cell line. Genomics 101(4):213-220. doi:10.1016/j.ygeno.2012.11.009. 
Anampa J, Makower D, Sparano JA. 2015. Progress in adjuvant chemotherapy for breast cancer: an overview. BMC Med. 13(1):195. doi:10.1186/s12916-015-04398.

Balunas MJ, Kinghorn AD. 2005. Drug discovery from medicinal plants. Life Sci. 78(5):431-441. doi:10.1016/j.lfs.2005.09.012.

Chou TC. 2010. Drug combination studies and their synergy quantification using the Chou-Talalay method. Cancer Res. 70(2):440-446.

Deep G, Agarwal R. 2008. New combination therapies with cell-cycle agents. Curr Opin Investig Drugs 9(6):591-604.

Dias DA, Urban S, Roessner U. 2012. A historical overview of natural products in drug discovery. Metabolites 2(4):303-336. doi:10.3390/metabo2020303.

Elmore S. 2007. Apoptosis: a review of programmed cell death. Toxicol Pathol. 35(4):495-516. doi:10.1080/01926230701320337.

Foucquier J, Guedj M. 2015. Analysis of drug combinations: current methodological landscape. Pharmacol Res Perspect. 3(3):e00149. doi:10.1002/prp2.149.

Hanahan D, Weinberg RA. 2011. Hallmarks of cancer: the next generation. Cell 144(5):646-674. doi:10.1016/j.cell.2011.02.013.

Kamil N, Kamil S. 2015. Global cancer incidences, causes and future predictions for subcontinent region. Syst Rev Pharm. 6(1):13-17.

Ko EY, Moon A. 2015. Natural products for chemoprevention of breast cancer. J Cancer Prev. 20(4):223-231. doi:10.15430/JCP.2015.20.4.223.

Lal S, Mahajan A, Chen WN, Chowbay B. 2010. Pharmacogenetics of target genes across doxorubicin disposition pathway: a review. Curr Drug Metab. 11(1):115128. doi:10.2174/138920010791110890.

Ma X, Yu H. 2006. Global burden of cancer. Yale J Biol
Med. 79(3-4):85-94.

Reynolds CP, Maurer BJ. 2005. Evaluating response to antineoplastic drug combinations in tissue culture models. Methods Mol Med. 110:173-183. doi:10.1385/159259-869-2:173.

Riss TL, Moravec RA, Niles AL, Duellman S, Benink HA, Worzella TJ, Minor L. 2016. Cell viability assays. In: G Sittampalam, N Coussens, K Brimacombe, A Grossman, M Arkin, et al, editors. Assay guidance manual [Internet]. Bethesda (MD): Eli Lilly \& Company and the National Center for Advancing Translational Sciences.

Schwartz GK, Shah MA. 2005. Targeting the cell cycle: a new approach to cancer therapy. J Clin Oncol. 23(36):9408-9421. doi:10.1200/JCO.2005.01.5594.

Shah MA, Schwartz GK. 2001. Cell cycle-mediated drug resistance: an emerging concept in cancer therapy. Clin Cancer Res. 7(8):2168-2181.

Tacar O, Sriamornsak P, Dass CR. 2013. Doxorubicin: an update on anticancer molecular action, toxicity and novel drug delivery systems: doxorubicin cell and molecular biological activity. J Pharm Pharmacol. 65(2):157-170. doi:10.1111/j.20427158.2012.01567.x.

Wang S, Konorev EA, Kotamraju S, Joseph J, Kalivendi S, Kalyanaraman B. 2004. Doxorubicin induces apoptosis in normal and tumor cells via distinctly different mechanisms. intermediacy of $\mathrm{H}(2) \mathrm{O}(2)-$ and $\mathrm{p} 53$ dependent pathways. J Biol Chem. 279(24):2553525543. doi:10.1074/jbc.M400944200.

Wong RS. 2011. Apoptosis in cancer: from pathogenesis to treatment. J Exp Clin Cancer Res. 30(1):87. doi:10.1186/1756-9966-30-87.

Zeichner SB, Terawaki H, Gogineni K. 2016. A review of systemic treatment in metastatic triplenegative breast cancer. Breast Cancer 10:25-36. doi:10.4137/BCBCR.S32783. 